\title{
Heritabilities for several colony traits in the honeybee (Apis mellifera carnica)
}

\author{
K Bienefeld *, F Pirchner
}

\author{
Lehrstuhl für Tierzucht der TU München, 8050 Freising-Weihenstephan, FRG
}

(Received 1 September 1989, accepted 29 March 1990)

\begin{abstract}
Summary - Colony traits in honeybees result from the sum of the queen contribution and of an average contribution of the workers. To estimate separately the heritability of queen and worker effects, observed covariances of related colonies are expressed as functions of theoretical causal components of phenotypic variance. Covariances were estimated by REML (Restricted Maximum Likelihood) and weighted parent-offspring covariance analysis. Causal components are estimated by weighted least squares analysis of this system of equations. The data $(n=5581)$ come from an Apis mellifera carnica population in northern and mid-Germany. Honey and wax production have medium $h^{2}$ values for worker $(0.26 / 0.39)$ and queen effects $(0.15 / 0.45)$. The corresponding values for aggressiveness, calmness during examination and spring development were higher. Strongly negative genetic correlations were found between worker and queen effects with respect to all colony traits. This negative genetic relationship impedes selection response, since it reduces the phenotypic variance within population, and therefore tends to stabilize it at a particular value.
\end{abstract}

heritability / colony trait / genetic correlation / queen effect / worker effect / colony selection

\section{INTRODUCTION}

The main complication in the estimation of heritabilities $\left(h^{2}\right)$ of colony traits in honeybees arises from the fact that many characters of economic value are affected by the combined activity of many workers (hoarding behavior, life-span, production of and reaction to isopentyl acetate, etc) and the queen (laying capacity, pheromone production, etc). Two approaches were used to overcome this difficulty. The first method restricted heritability estimates to either queen or worker characters (eg hoarding behavior, corbicular area, etc), which are expected to show high correlations to the performance of the entire colony (Rinderer et al, 1983; Collins et al, 1984; Milne, 1985a, 1985b, 1985c; Collins et al, 1987).

The second method neglected the participation of 1 caste in the colony performance and interpreted the covariance between related colonies exclusively from the genetic relationship between either the queens (Vesely and Siler, 1964; Soller and

\footnotetext{
* Present address: Institut für Bienenkunde (Polytechnische Gesellschaft), Fachbereich Biologie der JW Goethe - Universität, Frankfurt/Main, Karl-von-Frisch-Weg 2, 6370 Oberursel, FRG
} 
Bar-Cohen, 1967; Böger, 1969; BarCohen et al, 1978) or the offspring worker groups (Pirchner et al, 1962). Chevalet and Cornuet (1982) proposed to handle colony traits like composite mammalian characters with maternal influences in addition to direct effect.

Dickerson (1947) and Willham (1963) developed a model for mammalian traits like juvenile growth, which are affected both by the offspring whose growth is measured and by its dam who furnishes the developmental environment during the period. The situation in the honeybee can be seen in an analogous fashion. Honey production, aggressiveness, etc, are measured on workers, but these characters are composed of at least 2 distinct components: hoarding activity, life-span, behavior, etc, of the workers, and a maternal effect (laying capacity, pheromone production) contributed by a related individual, the queen. While the maternal contribution is strictly environmental relative to the offspring, genotypic differences among dams (for the maternal effect) are expressed in the offspring.

\section{MATERIAL AND METHODS}

Pedigree information and results from performance testing of 5581 colonies from controlled- mating were provided by two bee breeding organisations in Lower Saxony (FRG), a breeding society in Hamburg (FRG) and the bee breeding institutes in Celle (FRG), Kirchhain (FRG) and Lunz (Austria) from 1951 to 1984 . Honey yield was measured as weight difference of combs before and after extraction of honey, plus an estimate of honey left in the broodnest. Wax production was estimated by the number of honey and brood combs times a factor between 0.06 and 0.07 . Aggressiveness, calmness during examination and spring development were judged subjectively, scored as 1 (very bad) to 4 (very good). Intermediate marks were possible. Number, means and standard deviation of the recorded colony traits are summarized in table 1 . Details of this data set are given by Bienefeld $\theta t$ al (1989); the procedure of the performance tests is fully described by Ruttner (1972).

The queens were mated by drones of known descent on island mating stations. On average, 6 drone-producing queens, all daughters of 1 queen, provided the drones on these islands. Polhemus et al (1950) pointed out that the haploid drone can be considered as a random sample of identical gametes from his female parent. Considering drone-producing queens as sires, pedigrees with 1 modification are comparable to those of ordinary diploid animals. Since it is not possible, under our conditions, to associate a female (queen or worker) to a single droneproducing queen (genetic sire), the dam of these drone-producing queens is the genetical reference; they are called "sires" (fig 1).

The number of sires of workers (SW), sires of queens $(S Q)$ and dams of queens $(D Q)$ and their average number of offspring are presented in table II.

Table I. Measured colony traits. P: Scored subjectively from 1 (worst) to 4 (best).

\begin{tabular}{lcccccr}
\hline Traits & Unit & $\mathrm{n}$ & $\bar{x}$ & $s$ & $\min$ & $\max$ \\
\hline Honey & $(\mathrm{kg})$ & 5342 & 24.1 & 13.9 & 0.0 & 99.8 \\
Wax & $(\mathrm{kg})$ & 1724 & 0.86 & 0.33 & 0.0 & 2.0 \\
Aggressiveness & $(\mathrm{P})$ & 2770 & 3.73 & 0.63 & 1.0 & 4.0 \\
Calmness & $(\mathrm{P})$ & 2764 & 3.72 & 0.54 & 1.0 & 4.0 \\
Spring development & $(\mathrm{P})$ & 2177 & 3.42 & 0.69 & 1.0 & 4.0 \\
\hline
\end{tabular}




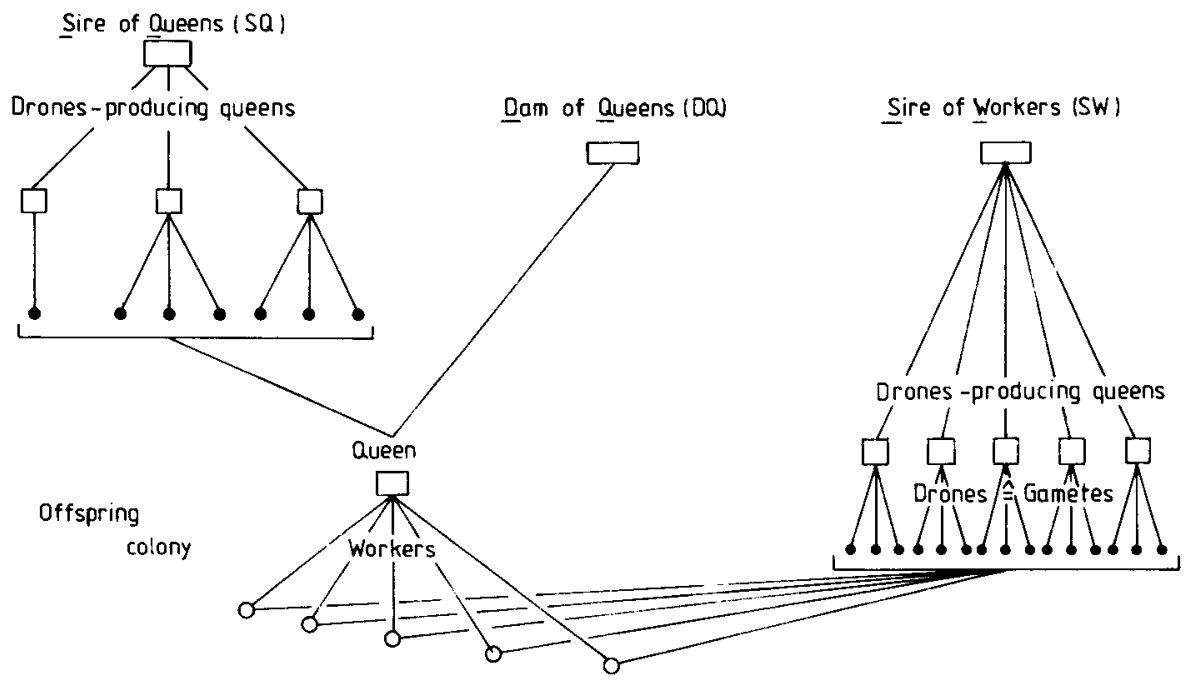

Fig 1. Descent of controlled mated colonies (island mating or antificial insemination).

\section{Statistical model}

Let $P_{X}$ represent the phenotypic value of colony $X$. Denote the 2 components of these characters as $w$ and $q$ symbolizing the worker component (workers $X$ ) and the queen effect ( $V$ dam of workers $X$ ), and $G$ and $E$ as genotypic and environmental values, respectively, of colony $X$ for component $w$ and $q$ as expressed in $P_{X}$.

$$
\begin{aligned}
& P_{X}=G_{W X}+E_{W X}+G_{Q V}+E_{Q V} \\
& P_{Y}=G_{W Y}+E_{W Y}+G_{Q Z}+E_{Q Z}
\end{aligned}
$$

When dominance and epistatic effects are neglected, the covariance between $P_{X}$ and $P_{Y}$ (where for $P_{Y}$, worker $Y$ and queen $Z$ contribute components $w$ and $q$, respectively) is:

$$
\begin{aligned}
\operatorname{Cov}\left(P_{X}, P_{Y}\right)= & a_{X Y} \sigma_{W}^{2}+\left(a_{X Z}+a_{Y}\right) \sigma_{W Q} \\
& +a_{Z V} \sigma_{Q}^{2}
\end{aligned}
$$

where $\sigma^{2} W$ and $\sigma_{Q}^{2}$ symbolize the additive genetic variances for component $w$ and $q$, and $\sigma_{w O}$, the additive genetic covariance between the components $w$ and $q$. The coefficients $a_{Y X}$,

Table II. Number of dams of queens (DQ), sires of queens (SQ) and sires of workers (SW) and their average number of offspring colonies.

Ancestor

Number

Offspring colonies per ancestor

$\bar{x} \quad \sin \quad \max$

$\begin{array}{lrrrrr}\text { DQ } & 698 & 7.7 & 6.9 & 1 & 51 \\ \text { SQ } & 231 & 24.2 & 29.1 & 1 & 270 \\ \text { SW } & 275 & 20.3 & 21.3 & 1 & 117\end{array}$


$a_{X Z}, a_{Y V}$ and $a_{Z V}$ are twice Malecot's (1948) "coefficient de parenté" (Willham, 1963).

However, the pecularities of honeybee reproduction cause difficulties in estimating these genetic relationships (a). The large number of workers per colony permits us to accept an "average worker contribution". For that reason, "a" between 2 average worker genotypes of 2 different colonies are equivalent to " $a$ " between 2 "average workers" from these colonies.

The average genetic relationship between 2 females (queens or "an average worker") can be calculated as

$$
a=\frac{\phi+\sum P_{1} \phi_{1}^{\prime}}{2}
$$

$\phi=$ probability of identity of maternal genes in 2 females, $\phi_{i}^{\prime}=$ probability of identity of paternal genes in 2 females, depending on whether 2 random females are derived from the same drone, from different drones or the same droneproducing queen, or from different drones of different (but related) drone-producing queens.

$P_{1}=$ probability of these 3 possibilities, which are a function of the average number of droneproducing queens on the island-mating station and of the number of mating partners per queen.

The calculation of the "coefficient de parenté" assumes an unrelated base population. Bienefeld et al (1989) found a high rate of inbreeding in some colonies, but since average inbreeding levels did not exceed $5 \%$ per generation, we tolerated the omission of possible genetic relationships between parents.

Assuming the number of drone-producing queens per mating station as 6 (notes from the bee breeding organisation) and the number of drones per queen as 8 (Laidlaw, 1974; Woyke, 1985), genetic relationships in the honeybee are computable. The genetic relationships between queens, worker groups, and queen and worker groups, respectively, of different related colonies used in this study, are summarized in table III. The computing method is fully described by Bienefeld et al (1989). However, the accuracy of the coefficients of the genetic relationship depends on the validity of these assumptions made (on average, 8 drones per queen and 6 drone-producing queens per mating station) and whether, in this population, the breeding scheme (fig 1) was near the equilibrium:

$$
\phi_{t}=\phi_{t-1}
$$

Variation of the influencing factors in a realistic range (drones from 5-11 and droneproducing queens from 4-9) does not cause any serious deviation from the assumed situation (Bienefeld ot al, 1989). Starting from the first generation, with possible natural mating, the convergence to the equilibrium values (table III) is rapid ( $\phi_{3}=98 \%$ of $\left.\phi_{\infty}\right)$, so that in addition, this aspect only has a negligible influence on the parameter estimates.

The following 4 observational components of variance are estimated first by various methods, to obtain simultaneous estimates of $\mathbf{3}$ genetic $\left(\sigma^{2}{ }_{w}, \sigma^{2}{ }_{Q}, \sigma_{w \alpha}\right)$ parameters.

1) $\operatorname{Cov}(p H S)=$ covariance between colonies related by the same $S W$,

2) $\operatorname{Cov}(m H S)=$ covariance between colonies related by the same $D Q$,

3) $\operatorname{Cov}(O, D Q)=$ covariance between $D Q$ and offspring colonies,

4) $\operatorname{Cov}(O, S W)=$ covariance between $S W$ and offspring colonies,

where $p H S, m H S, S W, D Q$ denote, respectively, "paternal halfsibs", "maternal halfsibs", sire of workers and dam of queens.

Observational components 1 and 2 are estimated directly by computing the covariance between ancestors' performance and the weighted (according to Searle, 1971) offspring mean.

Observational components 3 and 4 are estimated by the "Restricted Maximum-Likelihood" method (Patterson and Thompson, 1971). The statistical model included location within year and bee breeder, $S Q$ and $D Q$ within $S Q$ and $S W$. Location within year and bee breeder and $S Q$ were considered to be fixed effects, all others were random. Because of non-normal distributions, the subjectively judged traits (aggressiveness, calmness and spring development) were transformed (e Variable).

The genetic parameters are estimated by applying the methods of least squares, where the dependent variable is the covariance among the specified set of relatives, the independent variables are the expected coefficients (table III) of the above 3 genetic components of variance 
Table III. Theoretical causal components of observed covariances. Given: 6 drones-producing queens per island mating station (notes from the bee breeding societies in Lower Saxony) and 8 drones per queen (Laidlaw, 1974; Woyke, 1985).

Covariances

$\sigma^{2} w$
Components

$\sigma_{Q}^{2} \quad \sigma_{w Q}$

$\begin{array}{llll}\operatorname{Cov}(\mathrm{pHS}) & 0.1306 & 0.0000 & 0.0000 \\ \operatorname{Cov}(\mathrm{mHS}) & 0.0742 & 0.2968 & 0.2968 \\ \operatorname{Cov}(\mathrm{O}, \mathrm{DQ}) & 0.2134 & 0.5000 & 0.6767 \\ \operatorname{Cov}(\mathrm{O}, \mathrm{SW}) & 0.2134 & 0.0000 & 0.2500\end{array}$

and the partial regression coefficients to be estimated are the 3 causal components of variance.

To solve these causal components, the coefficients in table III are used as a design matrix $X$, the observational components as an observation vector $y$, and the variances of and the covariances between the observational components are used as elements of square matrix $V$. Covariances between the components Cov (pHS), Cov (mHS) respectively and $\operatorname{Cov}(O$, $D Q), \operatorname{Cov}(O, S W)$ respectively are assumed to be zero. The causal components are then estimated as elements of the vector

$$
b=\left(X^{\prime} V^{-1} X\right)^{-1} X^{\prime} v^{-1} y
$$

By definition, the heritability of worker effects $\left(h^{2} w\right)$, queen effects $\left(h^{2} \alpha\right)$ and the genetic correlation between these ( $\left.r_{W Q}\right)$ are given by:

$h^{2}{ }_{W}=\frac{\sigma^{2}{ }_{W}}{\sigma^{2} P} \quad h_{Q}^{2}=\frac{\sigma_{Q}^{2}{ }_{Q}}{\sigma^{2} P} \quad r_{W Q}=\frac{\sigma_{W Q}}{\sigma_{W} \sigma_{Q}}$ where $\sigma_{p}^{2}$ is the total phenotypic variance.

The standard errors are derived by an approximation through Taylors series (Kendall and Stuart, 1969).

\section{RESULTS AND DISCUSSION}

The estimates of heritability of worker and queen effects and the genetic correlations between them are presented in table IV. The production traits (honey and wax) show medium $h^{2}$ values for both effects.

Heritability values have been published for honey production $(0.07-0.58)$ using conventional (offspring-dam regression and sister-queens covariance) estimation methods (Pirchner et al, 1962; Vesely and Siler, 1964; Soller and Bar-Cohen, 1967; Böger, 1969; Malkow et al, 1976; BarCohen et al, 1978).

Table IV. Heritabilities for several colony traits.

\begin{tabular}{llcc}
\hline Trait & $\mathrm{h}^{2}{ }_{\mathrm{w}} \pm$ se & $\mathrm{h}^{2}{ }_{\mathrm{Q}} \pm$ se & $\mathrm{r}_{\mathrm{WQ}} \pm$ se \\
\hline Honey & $0.26 \pm 0.10$ & $0.15 \pm 0.11$ & $-0.88 \pm 0.16$ \\
Wax & $0.39 \pm 0.31$ & $0.45 \pm 0.26$ & $-0.96 \pm 0.13$ \\
Aggressiveness & $0.41 \pm 0.25$ & $0.40 \pm 0.25$ & $-0.91 \pm 0.15$ \\
Calmness & $0.91 \pm 0.22$ & $0.58 \pm 0.21$ & $-0.96 \pm 0.05$ \\
Spring develop & $0.76 \pm 0.54$ & $0.46 \pm 0.40$ & $-0.92 \pm 0.09$
\end{tabular}


However, previously published results did not derive from data of normal performance tests, nor was the covariance between queen and worker effects taken into consideration. The first aspect tends to increase, the second (if $\sigma_{W Q}<0$ ) to lower, $h^{2}$ values of colony performances.

Heritabilities for behavior characters were higher than for production traits. Moritz et al (1987) also found their $h^{2}$ estimate for defense behavior $(0.3-0.8)$ relatively high, compared to equivalent values for honey production and brood rearing (Pirchner et al, 1962; Soller and BarCohen, 1967).

$\operatorname{Cov}(m H S)$ (in $\sigma^{2} \alpha$ ) and $\operatorname{Cov}(O, D Q$ ) (in $\left.\sigma_{W Q}\right)$ contain dominance effects and, as with the other covariances, epistatic effects. These non-additive genetic effects are assumed to be of minor magnitude compared to the additive genetic portion, and therefore, they are normally neglected. However, little is known about their importance from other species, and even less from Apis.

Moritz et al (1987) used a somewhat different method, but they also observed maternal influences on worker behavior. Findings by Bienefeld et al (1989), who found significantly more restless colonies headed by inbred queens, support the conclusion that the behavior of workers is also influenced by the queen's phenotype.

Velthuis (1977) reported a stabilizing effect of queen pheromones on colony behavior. Hoffmann (1961) found queenless colonies to be more irritable. Therefore, the heritable queen effect may be attributable in part to genetic differences in queen's pheromone production.

The most remarkable result is the distinct negative correlation between queen and worker effects. As yet, there are no comparable findings in the honeybee, but in cattle (Koch, 1972; Barlow, 1978; Trus and Wilton, 1988), swine (Kuhlers et al, 1977) and mice (Eisen et al, 1970; Hanrahan and Eisen, 1973), negative covariances were found between direct (growth of offspring) and maternal effects (promotion by its dam) during the suckling period.

Lerner (1950) assumed that the genetic correlation between 2 characters would eventually become negative if selection was applied to both traits simultaneously.

Those pleiotropic genes that affect both characters in the desired direction will be acted on strongly by selection and brought rapidly towards fixation, whereas pleiotropic genes that affect 1 character favorably and the other adversely will be influenced much less by selection and will remain at intermediate frequencies (Lerner, 1950; Falconer, 1981).

The medium to high $h^{2}$ values for queen and worker effects indicate a moderately high level of genetic variance. This may be explained as a consequence of negative correlation between direct and maternal effects.

The regression of the combined genotype $\left(G_{O X}+G_{M X}\right)$ on $P_{X}$ was shown by Dickerson (1947) to be

$$
=\frac{\sigma^{2} G O+1.5 \sigma_{G O G M}+0.5 \sigma^{2} G M}{\sigma^{2} P}
$$

In our terminology, $G_{O}$ and $G_{M}$ correspond to genotypes for workers $\left(G_{W}\right)$ and queens $\left(G_{Q}\right)$, respectively. In honeybees, one would wish to predict the genotype of a potential queen from colony $X$. Therefore, since the genetic relationship between individuals within a colony was calculated to be 0.43 in our breeding scheme, the regression will be:

$$
\mathrm{h}^{2}=\frac{0.43 \sigma^{2} w+0.93 \sigma_{W Q}+0.5 \sigma^{2} Q}{\sigma^{2} P}
$$


A negative value of $\sigma_{W Q}$ has the consequence that sufficient genetic variance with respect to worker and queen effects do not translate to equivalent variability of the entire colony performance, which is the real unit of selection. The reduced phenotypic variance tends to hold a population to a particular value, perhaps an optimum (Willham, 1963), but not necessarily caused by fixation of genes for queen and worker effects, respectively. This is possibly an advantage under natural conditions; however, in breeding programs in which honey production, calmness, etc, are the desired characters, the negative correlation hinders selection response. Hanrahan (1976) derived (in sheep) that when the ratio $h_{O} / h_{M}$ is less than $\left|r_{O M}\right|$ and $r_{O M}<0$, the regression of breeding value on the selection criterion is negative and response will even be in the direction opposite to that intended. An index that maximizes the sum of the queen and worker breeding values simultaneously should be used as selection criterion (Bienefeld and Pirchner, submitted).

\section{ACKNOWLEDGMENTS}

We wish to thank $F$ Tiesler (Bee breeding organisation Hannover and Weser-Ems), JH Dustmann and E Englert (Bee Research Institute, Celle), V Maul (Bee Breeding Institute, Kirchhain), H Pechhacker (Bee Breeding Institute, Lunz, Austria) and all beekeepers who participated in this study for providing the data. Financial support was provided by the Deutsche Forschungsgemeinschaft, grant no Pi 90/42.

\section{Résumé - Héritabilités de plusieurs} caractères des colonies chez l'abeille (Apis mellifica carnica). Les caractères des colonies représentent aussi bien le phénotype moyen des ouvrières que celui de la reine (Chevalet et Cornuet, 1982). II est donc difficile d'en estimer l'héritabilité par les méthodes conventionnelles. Un modèle (Willham, 1963), développé pour des caractères à influence maternelle chez de jeunes mammifères, a été utilisé pour estimer l'héritabilité $\left(h^{2}\right)$ des effets "reine" et des effets "ouvrières" pour quelques caractères. La pléiotropie peut introduire une corrélation génétique supplémentaire entre les effets "reine" et les effets "ouvrières", dont il faut tenir compte même avec la méthode mentionnée cidessus. Les covariances entre colonies diversement apparentées $(n=5581)$ ont été estimées par la méthode du maximum de vraisemblance (Patterson et Thompson, 1971) ou par analyse de la covariance parents-enfants (Searle, 1971) et ont été exprimées en fonction des valeurs théoriques attendues (tableau III). Par résolution du système d'équations résultant (méthode des moindres carrés), il a été possible d'estimer les paramètres génétiques recherchés (Searle, 1971). Les données proviennent d'une population d'Apis mellifica carnica du Nord et du Centre de l'Allemagne. Les productions de miel et de cire ont des valeurs de $h^{2}$ moyennes pour les effets "reine" $(0,15 / 0,45)$ et les effets "ouvrières" $(0,26 / 0,39)$. Les valeurs correspondantes pour l'agressivité, le calme pendant l'examen des ruches et le développement printanier sont plus élevées (tableau IV). Des corrélations génétiques fortement négatives ont été trouvées entre les effets "reine" et les effets "ouvrières" pour tous les caractères des colonies. Cette relation génétique négative entrave l'efficacité de la sélection, puisqu'elle limite la variance phénotypique à l'intérieur de la population et tend donc à la stabiliser à une valeur donnée.

héritabilité / caractère des colonies / corrélation génétique / effet reine / effet ouvrière / sélection des colonies 
Zusammenfassung - Heritabilitäten von Volkseigenschaften bei der Honigbiene (Apis mellifera carnica). Eigenschaften des Bienenvolkes repräsentieren sowohl den durchschnittlichen Phänotyp der Arbeiterinnen als auch den der Königin (Chevalet and Cornuet, 1982). Die Anwendung konventioneller Methoden der Heritabilitätsschätzung ist somit bei Arbeiterinner und Königinnenwirkungen beinhal ten den Volkseigenschaften problematisch. Ein für maternal beeinflußte Jungtierleistungen bei Säugern entwickelter Ansatz (Willham, 1963) wurde verwendet, um Heritabilitäten für Königinner und Arbeiterrinneneffekte bei einigen Leistungseigenschaften $\mathrm{zu}$ schätzen. Wegen Pleiotropie ist zusätzlich noch eine genetische Korrelation zwischen Königinnen- und Arbeiterinneneffekten möglich, die ebenfalls mit oben erwähnter Methode zu berechnen ist. Hierbei werden die aus den Daten mit REML (Patterson und Thompson, 1971) bzw gewichteter Eltern-Nachkommen-Kovarianzanalyse (Searle, 1971) geschätzten Kovarianzen unterschiedlich verwandter ( $n=5$ 581) Völker als Funktionen der theoretischen Erwartungswerte (Tabelle III) ausgedrückt. Durch Lösung (gewichtete "Least Squares" - Methode) des sich ergebenden Gleichungssystems konnten die genetischen Parameter geschätzt werden (Searle, 1971). Die Daten stammen aus der Apis mellifera carnica Population Nord- und Mitteldeutschlands.

Honig- und Wachsproduktion zeigten mittlere Heritabilitäten für Arbeiterinnen (0.26/0.39) und Königinneneffekte $(0.15 /$ 0.45). Die entsprechenden Werte für $\mathrm{Ag}$ gressivität, Wabensitz und Frühjahrsentwicklung waren höher (Tabelle IV). Bei allen Volkseigenschaften errechneten sich ausgeprägt negative Korrelationen zwischen Königinnen- und Arbeiterinneneffekten. Die negative genetische Beziehung behindert den Selektionserfolg, da diese die phänotypische Varianz der Volksleistungen einschränkt und damit die Population eher auf einem bestimmten MerkmaIswert verharren läßt.

Heritabilität / Volkseigenschaft / genetische Korrelation / Königinneneffekte / Arbeiterinneneffekte / Volksselektion

\section{REFERENCES}

Bar-Cohen R, Alpern G, Bar-Anan R (1978) Progeny testing and selecting Italian queens for brood area and honey production. Apidologie 9, 95-100

Barlow R (1978) Biological ramification of selection for pre weaning growth in cattle. Anim Breed Abstr 46, 469-496

Bienefeld K, Reinhard F, Pirchner F (1989) Inbreeding effects of queen and workers on colony traits in the honeybee. Apidologie 20, $439-450$

Böger K (1969) Zur Selektion von Bienenvölkern auf Sammelleistung. $Z$ Bienenforsch 9, 545564

Chevalet C, Cornuet JM (1982) Etude théorique sur la sélection du caractère «production de miel» chez l'abeille. I. Modèle génétique et statistique. Apidologie 13, 39-65

Collins AM, Rinderer TE, Harbo JR, Braun MA (1984) Heritabilities and correlations for several characters in the honey bee. $J$ Hered 75, 135-140

Collins AM, Braun MA, Rinderer TE, Harbo JR, Tucker KW (1987) Heritabilities of honey-bee alarm pheromone production. $J$ Hered 78 , 29-31

Dickerson GE (1947) Composition of hog carcasses as influenced by heritable differences in rate and economy of gain. Res Bull lowa Agric Exp Sta 354, 489-524

Eisen EJ, Legates JE, Robinson OW (1970) Selection for 12-day litter weight in mice. Genetics $64,511-532$

Falconer DS (1981) Introduction to Quantitative Genetics. Longman Group Ldt, Longman House, UK 
Hanrahan JP (1976) Maternal effects and selection response with an application to sheep data. Anim Prod 22, 359-369

Hanrahan JP, Eisen EJ (1973) Sexual dimorphism and direct and matemal genetic effects on body weight in mice. Theor Appl Genet 43, 39-45

Hoffmann I (1961) Über die Arbeitsteilung in weiselrichtigen und weisellosen Kleinvölkern der Honigbiene. Z Bienenforsch 5, 267-279

Kendall MG, Stuart A (1969) The Advanced Theory of Statistics. Vol 1, Griffin and Company, London, 3rd ed

Koch RM (1972) The role of maternal effects in animal breeding. J Anim Sci 35, 1316-1323

Kuhlers DL, Capmann AA, First NL (1977) Estimates of maternal and grandmaternal influences on weights and gains of pigs. $J$ Anim Sci 44, 181-188

Laidlaw HH (1974) Die Verwandtschaftbeziehungen zwischen den Individuen eines Bienervolkes. Apiacta 9, 49-52

Lerner IW (1950) Population genetics and animal improvement. Cambridge University Press, Cambridge

Malécot G (1948) Les Mathématiques de I'Hérédité. Masson, Paris

Malkow WW, Timoschinova AE, Tschjapligin WP (1976) Variabilität and Vererbung der ökonomisch wertvollen Charakteristica bei den Bienen des Oka-Ökotyps. In: Genetik, Selektion und Reproduktion bei der Honigbiene. Apimondia, Bukarest, 196-198

Milne CP (1985a) An estimate of the heritability of the corbicular area of the honeybee. $J$ Apic Res 24, 137-139

Milne CP (1985b) An estimate of the heritability of worker longevity or length of life in the honeybee. J Apic Res 24, 140-143

Milne CP (1985c) A heritability estimate of honeybee hoarding behavior. Apidologie 16, 413-420

Moritz RFA, Southwick EE, Harbo JB (1987) Genetic analysis of defensive behaviour of honeybee colonies (Apis mellifera) in a field test. Apidologie 18, 27-42
Patterson HD, Thompson R (1971) Recovery of inter-block information when block sizes are unequal. Biometrika 58, 545-554

Pirchner F, Ruttner F, Ruttner H (1962) Erbliche Unterschiede zwischen Ertragseigenschaften von Bienen. XI. Int Congr Entomol Vienna 2, 501-516

Polhemus MS, Lush JL, Rothenbuhler WC (1950) Mating systems in honeybees. $J$ Hered 41, 151-154

Rinderer TE, Collins AM, Brown MA (1983) Heritabilities and correlations of the honey bee: response to Nosema Apis, longevity and alarm response to Isopentyl Acetate. Apidologie 14, 79-85

Ruttner F (1972) Technische Empfehlung zur Methodik der Leistungsprüfung von Bienenvölkern. In: Paarungskontrolle und Selektion bei der Honigbiene. Int Symp Lunz am See (österreich), Apimondia, Verlag, Bukarest, 103-107

Searle SR (1971) Linear Models. John Wiley \& Sons, New York

Soller M, Bar-Cohen R (1967) Some observations on the heritability and genetic correlation between honey production and brood area in the honey bee. J Apic Res 6, 37-43

Trus D, Wilton JW (1988) Genetic parameters for maternal traits in beef cattle. Can J Anim Sci $68,119-128$

Velthuis HHW (1977) The evolution of honeybee queen pheromones. Proc VIII Int Congr IUSSI, Wageningen, 220-222

Vesely V, Siler R (1964) Die Verwendungsmöglichkeit der quantitativen und Populationsgenetik bei der Rassezucht von Bienen. Proc 19 Int Beekeeping Congr, Apimondia, Bukarest, 2, 534-536

Willham RL (1963) The covariance between relatives for characters composed of components contributed by related individuals. Biometrics 19, 18-27

Woyke $J$ (1985) Instrumental insemination of honey bee queens in the development of bee keeping. World Anim Rev 56, 40-44 